J. Amer. Soc. Hort. ScI. 116(4):594-598. 1991.

\title{
Nitrogen Fertilization and HPS Supplementary \\ Lighting Influence Vegetable Transplant Production. I. Transplant Growth
}

\author{
Jean Masson, Nicolas Tremblay ${ }^{1}$, and André Gosselin \\ Department of Phytology, Faculty of Agriculture and Food, Laval University, Sainte-Foy, Que. \\ G1K 7 P4 Canada
}

\begin{abstract}
Additional index words. constant feeding, fertigation, pretransplanting nutritional conditioning, nutrition, high pressure sodium lighting, Apium graveolens, Lactuca sativa, Brassica oleracea, Lycopersicon esculentum

Abstract. This experiment was initiated to determine the effects of supplementary lighting of $100 \mu \mathrm{mol} \cdot \mathrm{s}^{-1} \cdot \mathrm{m}^{-2}$ (PAR) in combination with four $\mathrm{N}$ rates $(100,200,300$, and $400 \mathrm{mg} \mathrm{N} / \mathrm{liter}$ ) on growth of celery (Apium graveolens L.), lettuce (Luctuca sativa L.), broccoli (Brassica oleracea italica L.), and tomato (Lycopersicon esculentum Mill.) transplants in multicellular trays. Supplementary lighting, as compared with natural light alone, increased shoot dry weight of celery, lettuce, broccoli, and tomato transplants by $22 \%, 40 \%, 19 \%$, and $24 \%$, and root dry weight by $97 \%, 42 \%, 38 \%$, and $21 \%$, respectively. It also increased the percentage of shoot dry matter of broccoli and tomato, leaf area of lettuce and broccoli, and root : shoot dry weight ratio (RSDWR) of celery and broccoli. Compared with $100 \mathrm{mg} \mathrm{N} / \mathrm{liter}$, a $\mathrm{N}$ rate of $400 \mathrm{mg} \cdot$ liter $^{-1}$ increased the shoot dry weight of celery, lettuce, broccoli, and tomato transplants by $37 \%, 38 \%, 61 \%$, and $38 \%$, respectively. High $\mathrm{N}$ fertilization accelerated shoot growth at the expense of root growth, except for tomato where a $16 \%$ increase of root dry weight was observed. High $\mathrm{N}$ also reduced percentage of shoot dry matter. Supplementary lighting appears to be a promising technique when used in combination with high $\mathrm{N}$ rates to improve the production of high quality transplants, particularly those sown early.
\end{abstract}

According to Tosi and Tesi (1987), transplants with optimal vegetative development can better withstand the stresses caused by the field environment, pests, and diseases following transplanting. Specific characteristics are claimed to be necessary to lessen transplant shock and obtain maximum yield at harvest. For example, stem diameter of celery seedlings (Dufault, 1985) and of tomato transplants (Liptay et al., 1981) is an indication of their vigor and, according to Liptay et al. (1981), the accumulated reserves in tomato transplant stems enhance early fruiting.

High $\mathrm{N}$ levels used during celery transplant production have been found beneficial to yield of mature plants (Tremblay et al., 1987). In a subsequent study (Tremblay and Gosselin, 1989), a yield increase was obtained with high $\mathrm{N}$ only when $50 \%$ of it was provided as urea. However, urea generally did not have much influence on vegetable transplant vegetative characteristics (Tremblay and Senécal, 1990). High N levels are known to favor shoot rather than root growth. However, transplants with well-developed root systems are reported to recover more quickly from transplant shock (Weston and Zandstra, 1986).

The use of supplementary lighting may lessen the undesirable effects of high $\mathrm{N}$ on vegetative characteristics. An experiment on this topic conducted in Winter 1988 on lettuce and tomato transplants (Masson et al., 1990) confirmed that high rates of $\mathrm{N}$ fertilization increased shoot growth more than root growth. Supplementary lighting promoted a balance between shoot and root development and increased the percentage of shoot dry matter.

The objectives of our experiments were to: a) determine the effects of supplementary lighting and $\mathrm{N}$ fertilization on the growth

\footnotetext{
Received for publication 2 July 1990. We thank Yvon Perron, René Pouliot, and France Crochetière for their help. The cost of publishing this paper was defrayed in part by the payment of page charges. Under postal regulations, this paper therefore must be hereby marked advertisement solely to indicate this fact.

${ }^{1}$ Corresponding author: Agriculture Canada Research Station, 430 Gouin Blvd., Saint-Jean-sur-Richelieu, Que. J3B 3E6 Canada.
}

of celery, lettuce, broccoli, and tomato transplants during a normal production period; b) clarify the interactions of the two factors; and c) test the replicability of the treatments effects over time by means of two seeding dates for lettuce, and three for broccoli and tomato.

\section{Material and Methods}

\section{Plant material and growing conditions}

Plant material used included 'Florida 683' celery, 'Ithaca' lettuce, 'Premium Crop' broccoli, and 'Springset' tomato. Seeds were sown in multicell flats (Sutton plug trays \#288 for celery and lettuce, and \#128 for broccoli and tomato) using a peatbased substrate (Seeding Mix, Les tourbières Premier Ltée, Rivière-du-Loup, Quebec). The flats were placed in a polyethylene greenhouse, located at Laval Univ. (Quebec City). Tomato flats were placed on a table with heating cables that maintained the substrate at $24 \mathrm{C}$. The seedlings were thinned to one per cell when emergence was completed, and treatments were initiated at this stage. An early and a late seeding were performed for lettuce while early, midseason, and late seedings of broccoli and tomato were conducted. Celery was sown only once. Table 1 gives the dates for various operations. Overhead fertigation was performed twice daily to partial runoff. Seedlings were watered 1 day.week ${ }^{-1}$ with tap water to prevent an increase of salinity in the medium (Kratky and Mishima, 1981). Mean air temperature was maintained between 20 and $23 \mathrm{C}$ (day) and 17.0 and 18.OC (night) for the different species and seedlings during the course of the experiment.

\section{Treatments}

The transplants were under natural light (control) or under supplementary lighting. The latter was provided by $400-\mathrm{W}$ HPS

Abbreviations: LAR, leaf area ratio; RSDWR, root : shoot dry weight ratio; SLA, specific leaf area. 
Table 1. Seeding schedule, treatment initiation, and growth measurement dates of celery, lettuce, broccoli, and tomato transplants grown in multicellular trays under various supplementary lighting and $\mathrm{N}$ fertilization regimes.

\begin{tabular}{lcccc}
\hline \hline Species & Sowing & $\begin{array}{c}\text { Seeding } \\
\text { date }\end{array}$ & $\begin{array}{c}\text { Treatment } \\
\text { initiation }\end{array}$ & $\begin{array}{c}\text { Growth } \\
\text { measures }\end{array}$ \\
\hline Celery & Midseason & $30 \mathrm{Mar}$. & $7 \mathrm{Apr}$. & $16 \mathrm{May}$ \\
Lettuce & Early & $21 \mathrm{Apr}$. & $25 \mathrm{Apr}$. & $16 \mathrm{May}$ \\
& Late & $6 \mathrm{May}$ & $10 \mathrm{May}$ & 29 May \\
Broccoli & Early & $18 \mathrm{Apr}$. & $22 \mathrm{Apr}$. & $16 \mathrm{May}$ \\
& Midseason & $25 \mathrm{Apr}$. & $29 \mathrm{Apr}$. & 23 May \\
& Late & $11 \mathrm{May}$ & $16 \mathrm{May}$ & 6 June \\
Tomato & Early & $21 \mathrm{Apr}$. & 30 Apr. & 24 May \\
& Midseason & 3 May & 12 May & 2 June \\
& Late & 16 May & 24 May & 15 June \\
\hline
\end{tabular}

lights (No. 400-SO-SHP-120-Solux Lumiponic, Boisbriand, Quebec) giving a photosynthetic photon flux density (PPFD) of $100 \pm \mathrm{s}=10 \mu \mathrm{mol} \cdot \mathrm{s}^{-1} \cdot \mathrm{m}^{-2}$ photosynthetically active radiation (PAR) (72 measures) at the level of the multicell flats using a LI-COR LI-185 photometer equipped with a LI-COR LI-190SB (LI-COR, Lincoln, Neb.) quantum sensor. The lights were turned on before sunrise and off at sunset so as to have a 16-h photoperiod. The starting time for the lighting was changed once a week in relation to the time of sunset. The lights were lit during the day when natural PPFD was $<250 \mu \mathrm{mol} \cdot \mathrm{s}^{-1} \cdot \mathrm{m}^{-2}$. Table 2 presents available natural and artificial light energy and the number of hours of lighting per day for each species and seeding. Shade from the greenhouse structure caused a $60 \%$ loss of transmission. As recommended by Thimijan and Heins (1983), the data were also expressed as total natural and artificial light energy on a $24-h$ basis.

The fertilization treatments consisted of four nutrient solutions with $\mathrm{N}$ concentrations of 100, 200, 300, and $400 \mathrm{mg} \cdot \mathrm{liter}^{-1}$.
Nitrogen was provided according to a ratio of $\mathrm{N}-\mathrm{NO}_{3}$ : $\mathrm{N}-\mathrm{NH}_{4}: \mathrm{N}-$ Urea of $2: 1: 2$. All the nutrient solutions had the same concentrations (mg.liter ${ }^{-1}$ ) of $\mathrm{P}$ (150), K (250), Ca (50), $\mathrm{Mg}$ (20), Fe (2), Mn (0.5), Cu (0.03), B (2.5), Zn (0.05), and Mo (0.02). The $\mathrm{pH}$ of the nutrient solution was adjusted to 6.0 using $\mathrm{NaOH}$. The electrical conductivity was $1.89,2.03,2.16$, and $2.36 \mathrm{mS} \cdot \mathrm{cm}^{-1}$, respectively, for $100,200,300$, and 400 mg N/liter.

\section{Experimental design, characteristics measured, and statistical analysis}

The greenhouse was divided into four experimental blocks placed east-west. Each block was divided into two plots separated by curtains, where light treatments were divided at random. The curtains were drawn from 0800 to 1730 HR. For each species and seeding date, four multicell flats (subplots) were placed under each light treatment. A row of plants on the sides of the trays served as guard rows. The $\mathrm{N}$ fertilization treatments and seedlings were divided at random and the flats were regularly randomized within their lighting sections. The experimental units, made up of one multicell flat, were distributed in the greenhouse according to a split-plot design, with the lighting treatments as the main plots and the $\mathrm{N}$ fertilization treatments and seeding dates combination as subplots. Since celery was sown only once, the subplots contained only fertilization treatments.

The analysis of variance was performed for each species according to a split-plot design with the lighting treatment (two levels) as the main plots. The subplots for celery contained the $\mathrm{N}$ treatment (four levels), for lettuce it contained the $\mathrm{N}$ treatment and seeding date combination (four levels of $\mathrm{N}$ and two seeding dates) and for tomato and broccoli (four levels of $\mathrm{N}$ and three seeding dates). The experiment was done with four replications

Table 2. Contribution of natural and supplementary lighting to the light integral (PAR) received in the greenhouse by transplants for the various sowings.

\begin{tabular}{|c|c|c|c|c|c|c|c|}
\hline Sowing & $\begin{array}{l}\text { Lighting } \\
\text { level }\end{array}$ & $\begin{array}{c}\text { Lamṕ } \\
\text { use } \\
\left(\mathrm{h} \cdot \text { day }^{-1}\right) \\
\end{array}$ & $\begin{array}{c}\text { Natural } \\
\text { light integral } \\
(\mathrm{PAR}) \\
\left(\mathrm{W} \cdot \mathrm{m}^{-2} \cdot \text { day }^{-1}\right)\end{array}$ & $\begin{array}{c}\text { Supplemental } \\
\text { light integral } \\
(\mathrm{PAR}) \\
\left(\mathrm{W} \cdot \mathrm{m}^{-2} \cdot \mathrm{day}^{-1}\right)\end{array}$ & $\begin{array}{c}\text { Total } \\
\text { light integral } \\
(\mathrm{PAR}) \\
\left(\mathrm{W} \cdot \mathrm{m}^{-2} \cdot \text { day }^{-1}\right) \\
\end{array}$ & $\begin{array}{c}\text { Mean } \\
\text { light integral } \\
(24-\mathrm{h} \text { basis }) \\
\left(\mathrm{W} \cdot \mathrm{m}^{-2} \cdot \mathrm{h}^{-1}\right)\end{array}$ & $\begin{array}{c}\text { Increase } \\
\text { attributed to } \\
\text { suppl. lighting } \\
(\%) \\
\end{array}$ \\
\hline \multicolumn{8}{|c|}{ Celery } \\
\hline Midseason & Natural & 0 & 1094 & 0 & 1094 & 45.6 & -- \\
\hline Midseason & Supplemented & 12.5 & 1094 & 250 & 1344 & 56.0 & 22.8 \\
\hline \multicolumn{8}{|c|}{ Lettuce } \\
\hline Early & Natural & 0 & 1313 & 0 & 1313 & 54.7 & $\cdots$ \\
\hline Late & Natural & 0 & 1365 & 0 & 1365 & 56.9 & --- \\
\hline Early & Supplemented & 11.6 & 1313 & 232 & 1545 & 64.4 & 17.7 \\
\hline Late & Supplemented & 11.3 & 1365 & 226 & 1591 & 66.3 & 16.6 \\
\hline \multicolumn{8}{|c|}{ Broccoli } \\
\hline Early & Natural & 0 & 1208 & 0 & 1208 & 50.3 & --- \\
\hline Midseason & Natural & 0 & 1400 & 0 & 1400 & 58.3 & --- \\
\hline Late & Natural & 0 & 1433 & 0 & 1433 & 59.7 & --- \\
\hline Early & Supplemented & 11.8 & 1208 & 236 & 1444 & 60.2 & 19.5 \\
\hline Midseason & Supplemented & 10.5 & 1400 & 210 & 1610 & 67.1 & 15.0 \\
\hline Late .. & Supplemented & 9.6 & 1433 & 192 & 1625 & 67.7 & 13.4 \\
\hline \multicolumn{8}{|c|}{ Tomato } \\
\hline Early & Natural & 0 & 1337 & 0 & 1337 & 55.7 & --- \\
\hline Midseason & Natural & 0 & 1412 & 0 & 1412 & 58.8 & --- \\
\hline Late & Natural & 0 & 1428 & 0 & 1428 & 59.5 & --- \\
\hline Early & Supplemented & 11.5 & 1337 & 230 & 1567 & 65.3 & 17.2 \\
\hline Midseason & Supplemented & 9.9 & 1412 & 198 & 1610 & 67.1 & 14.0 \\
\hline Late & Supplemented & 9.7 & 1428 & 194 & 1622 & 67.6 & 13.6 \\
\hline
\end{tabular}


for all species. The Bartlett test was used $(\mathrm{P} \leq 0.01)$ to verify the homogeneity of variance.

When transplant stage was reached (Table 1), 15 celery and lettuce plants and 10 broccoli and tomato plants per experimental unit were sampled for growth measurements. The fresh and oven-dried (70C) weights were determined for leaves without petioles, stems with petioles, and roots previously washed. Leaf area was measured using a LI-COR LI-3000 (LI-COR) area meter. LAR was calculated by dividing leaf area by shoot (including stem, petiole, and leaf blade) dry weight. SLA (leaf blade area/leaf blade dry weight), RSDWR, and the percentage of shoot dry matter were also calculated.

Since the interactions between seeding date and the lighting and fertilization treatments are rare or marginally significant $(P \leq 0.05)$, we have combined the data and have only reported the averages for the three seedlings of tomato and broccoli. For lettuce, the more important interactions of treatments with seeding date are discussed in the text.

\section{Results and Discussion}

Shoot dry weight. Supplementary lighting significantly increased shoot dry weight of celery, lettuce, broccoli, and tomato by $22 \%, 40 \%, 19 \%$, and $24 \%$, respectively (Tables $3,4,5$, and $6)$. Dry weight accumulated in celery stalks but not in the leaf blade; for broccoli and tomato, both variables increased. According to Liptay et al. (1981), the reserves accumulated in tomato transplant stems promote earliness. Stem dry weight can be considered a good indicator of the radial growth of the transplants' base, which is evidence of the young plant's vigor (Dufault, 1985; Liptay et al., 1981).

High rates of $\mathrm{N}$ fertilization also increased shoot dry weight for all species (Tables 3,4,5, and 6). Nitrogen at $400 \mathrm{mg} \cdot$ liter $^{-1}$ increased celery, lettuce, broccoli, and tomato shoot dry weight by $37 \%, 38 \%, 61 \%$, and $38 \%$, respectively, compared with $\mathrm{N}$ at $100 \mathrm{mg} \cdot$ liter $^{-1}$. For celery and broccoli, shoot dry weight increased curvilinearly in relation to $\mathrm{N}$, whereas a linear response was obtained for tomato. Similar results for tomato were reported by Weston and Zandstra (1989). With celery, the increase of shoot dry weight with $\mathrm{N}$ rates was linear under natural light, but a plateau was reached under supplementary lighting at $300 \mathrm{mg} \mathrm{N} /$ liter. Tremblay et al. (1987) observed higher biomass at a rate of $400 \mathrm{mg}$ N/liter for celery transplants than at rates of 200 and $600 \mathrm{mg} \cdot$ liter $^{-1}$. In our study, $100 \mathrm{mg} \mathrm{N} /$ liter limited shoot growth under natural and supplementary lighting.
Response of lettuce shoot dry weight to $\mathrm{N}$ rates was complex but, under supplementary lighting, the highest shoot dry weight was obtained with $400 \mathrm{mg}$ N/liter.

Percentage of shoot dry matter. Supplementary lighting improved the percentage of shoot dry matter for broccoli, tomato (Tables 5 and 6), and lettuce (data not shown) but not for celery (Table 3). Tesi and Tallarico (1984) reported that an increase in percentage of shoot dry matter improves cold resistance and that a good tomato transplant should have $>10 \%$ dry matter. Increasing the $\mathrm{N}$ rate decreased the percentage of shoot dry matter in all species (Tables 3, 4, 5, and 6), with the lowest percentages obtained at highest level of $\mathrm{N}$ fertilization. A similar response was previously reported for celery, lettuce, broccoli, and pepper (Tremblay and Senécal, 1988; Tremblay et al., 1987). Transplants overfertilized with $\mathrm{N}$ show an increase in succulence and are easily broken when transplanted (Kratky and Mishima, 1981).

Leaf area, SLA, and LAR. Leaf area for lettuce and broccoli increased under supplementary lighting (Tables 4 and 5), but no effect was detected for celery and tomato (Tables 3 and 6). Supplementary lighting enhanced leaf area development for early tomato seeding only (data not shown). According to Boivin et al. (1986), leaf area is a poor indicator of the effect of light treatments on growth of tomato transplants. Supplementary lighting lowered the SLA of celery, broccoli, and tomato (Tables 3, 5, and 6), but not that of lettuce (Table 4). A low SLA is desirable since it is associated with greater leaf thickness. Leaf anatomy is changed by an increase in light energy (Salisbury and Ross, 1985), as is the case for the amount of chlorophyll and the chloroplasts (Björkman, 1981). Leaves adapt to high amounts of radiation, and one can generally observe an elongation of the palisade layer or the addition of a second layer of cells. Under high PPFD, the palisade layer cells generally elongate so that the leaves are thicker and a decrease in SLA is observed. A low SLA may make transplants more resistant to transplant shock. The increase in natural light energy associated with later seeding seemed to lessen the effect of supplementary lighting on the SLA of broccoli (data not shown) but not that of tomato.

The increase in leaf area with $\mathrm{N}$ fertilization (Tables 3, 4,5, and 6) is in agreement with several studies (Dufault, 1985, 1986; Tremblay and Senécal, 1988; Weston and Zandstra, 1989). Lettuce, broccoli, and tomato SLA increased with $\mathrm{N}$ rate in a curvilinear manner (Tables 4, 5, and 6), but celery was not

Table 3. Effect of supplementary lighting $\left(100 \mu \mathrm{mol} \cdot \mathrm{s}^{-1} \cdot \mathrm{m}^{-2}\right.$; PAR) and four $\mathrm{N}$ levels on celery transplant growth.

\begin{tabular}{|c|c|c|c|c|c|c|c|c|c|c|}
\hline \multicolumn{2}{|c|}{ Treatments } & \multirow{2}{*}{\multicolumn{4}{|c|}{$\begin{array}{c}\text { Dry wt } \\
\text { (mg/plant) }\end{array}$}} & \multirow{3}{*}{$\begin{array}{c}\text { Shoot } \\
\text { dry matter } \\
(\%)\end{array}$} & \multirow{3}{*}{$\begin{array}{c}\text { Leaf } \\
\text { area } \\
\left(\mathrm{cm}^{2} / \text { plant }\right)\end{array}$} & \multirow{3}{*}{$\begin{array}{c}\text { SLA } \\
\left(\mathrm{cm}^{2} \cdot \mathrm{mg}^{-1}\right)\end{array}$} & \multirow{3}{*}{$\begin{array}{c}\mathrm{LAR} \\
\left(\mathrm{cm}^{2} \cdot \mathrm{mg}^{-1}\right)\end{array}$} & \multirow[b]{3}{*}{ RSDWR } \\
\hline \multirow[b]{2}{*}{ Light } & \multirow{2}{*}{$\begin{array}{c}\mathrm{N} \\
\left(\mathrm{mg} \cdot \text { liter }^{-1}\right)\end{array}$} & & & & & & & & & \\
\hline & & Shoot & Stem & Leaf & Root & & & & & \\
\hline \multirow[t]{4}{*}{ Natural } & 100 & 123 & 52 & 71 & 12 & 8.5 & 31.4 & 0.44 & 0.25 & 0.10 \\
\hline & 200 & 134 & 58 & 76 & 8 & 8.0 & 33.5 & 0.44 & 0.25 & 0.06 \\
\hline & 300 & 133 & 58 & 75 & 7 & 7.7 & 32.8 & 0.44 & 0.25 & 0.05 \\
\hline & 400 & 146 & 65 & 81 & 9 & 7.7 & 35.7 & 0.44 & 0.24 & 0.06 \\
\hline \multirow[t]{4}{*}{ Supplementary } & 100 & 116 & 47 & 69 & 27 & 8.8 & 27.2 & 0.40 & 0.24 & 0.23 \\
\hline & 200 & 171 & 74 & 97 & 18 & 9.5 & 36.4 & 0.37 & 0.21 & 0.11 \\
\hline & 300 & 183 & 81 & 102 & 14 & 8.0 & 41.6 & 0.41 & 0.23 & 0.08 \\
\hline & 400 & 182 & 80 & 102 & 12 & 8.1 & 41.0 & 0.40 & 0.22 & 0.06 \\
\hline \multicolumn{11}{|l|}{ Significance $^{\mathbf{z}}$} \\
\hline \multicolumn{2}{|l|}{ Nitrogen } & $\mathrm{L}^{* * *}, \mathrm{Q}^{*}$ & $\mathrm{~L}^{* * *}, \mathrm{Q}^{*}$ & $\mathrm{~L}^{* * *}, \mathrm{Q}^{*}$ & $\mathrm{~L}^{* * *}$ & $\mathrm{~L}^{* *}$ & $\mathrm{~L}^{* * *}$ & NS & NS & $\mathrm{L}^{* * *}, \mathrm{Q}^{* * *}$ \\
\hline \multicolumn{2}{|c|}{ Light } & & $*$ & NS & $*$ & NS & NS & $* *$ & $* *$ & $*$ \\
\hline \multicolumn{2}{|c|}{ Nitrogen $\times$ light } & $\mathrm{L}^{* *}, \mathrm{Q}^{*}$ & $\mathrm{~L}^{*}, \mathrm{Q}^{*}$ & $\mathrm{~L}^{* *}, \mathrm{Q}^{*}$ & $\mathrm{~L}^{* *}$ & NS & $\mathrm{L}^{* *}, \mathrm{Q}^{*}$ & NS & NS & $\mathrm{L}^{* * *}$ \\
\hline
\end{tabular}

${ }^{2}$ Linear (L) or quadratic (Q) effects significant at $P=0.05\left({ }^{*}\right), 0.01\left({ }^{* *}\right)$, or $0.001\left({ }^{* * *}\right)$ or nonsignificant (NS) 
Table 4. Effect of supplementary lighting $\left(100 \mu \mathrm{mol} \cdot \mathrm{s}^{-1} \cdot \mathrm{m}^{-2} ; \mathrm{PAR}\right)$ and four $\mathrm{N}$ levels on lettuce transplant growth (averages of two seeding dates).

\begin{tabular}{|c|c|c|c|c|c|c|c|}
\hline \multicolumn{2}{|c|}{ Treatments } & \multicolumn{2}{|c|}{$\begin{array}{c}\text { Ury wt } \\
\text { (mg/plant) }\end{array}$} & \multirow{2}{*}{$\begin{array}{c}\text { Shoot } \\
\text { dry matter } \\
(\%)\end{array}$} & \multirow{2}{*}{$\begin{array}{c}\text { Leaf } \\
\text { area } \\
\text { (cm²/plant })\end{array}$} & \multirow{2}{*}{$\begin{array}{c}\text { SLA } \\
\left(\mathrm{cm}^{2} \cdot \mathrm{mg}^{-1}\right)\end{array}$} & \multirow[b]{2}{*}{ RSDWR } \\
\hline Light & $\left(\mathrm{mg} \cdot\right.$ liter $\left.^{-1}\right)$ & Shoot & $\operatorname{Root}^{\mathbf{z}}$ & & & & \\
\hline \multirow[t]{4}{*}{ Natural } & 100 & 85 & 9 & 6.0 & 34.2 & 0.41 & 0.11 \\
\hline & 200 & 91 & 7 & 5.4 & 38.9 & 0.43 & 0.08 \\
\hline & 300 & 99 & 8 & 5.2 & 43.9 & 0.45 & 0.08 \\
\hline & 400 & 97 & 6 & 5.0 & 43.3 & 0.45 & 0.07 \\
\hline \multirow[t]{4}{*}{ Suppleméntary } & 100 & 97 & 13 & 6.5 & 35.7 & 0.37 & 0.13 \\
\hline & 200 & 135 & 11 & 5.5 & 54.3 & 0.41 & 0.08 \\
\hline & 300 & 136 & 11 & 5.1 & 58.0 & 0.43 & 0.08 \\
\hline & 400 & 153 & 7 & 5.2 & 63.4 & 0.42 & 0.05 \\
\hline \multicolumn{8}{|l|}{ Significance ${ }^{y}$} \\
\hline Nitrogen & & $\mathrm{L}^{* * *}, \mathrm{Q}^{* *}, \mathrm{C}^{*}$ & $\mathrm{~L}^{* * *}$ & $\mathrm{~L}^{* * *}, \mathrm{Q}^{* * *}$ & $\mathrm{~L}^{* * *}, \mathrm{Q}^{* *}$ & $\mathrm{~L}^{* * *}, \mathrm{Q}^{*}$ & $\mathrm{~L}^{* * *}, \mathrm{Q}^{*}$ \\
\hline Light & & $* *$ & * & NS & $* *$ & NS & NS \\
\hline Nitrogen $\times 1$ & & $\mathrm{~L}^{* * *}, \mathrm{C}^{* *}$ & NS & $\mathrm{Q}^{*}$ & $\mathrm{~L}^{* * *}, \mathrm{Q}^{*}, \mathrm{C}^{*}$ & NS & $\mathrm{L}^{* *}$ \\
\hline
\end{tabular}

${ }^{z}$ One transformation, $(\mathrm{Y}+0.5)^{1 / 2}$, was necessary for this characteristic; the raw data are listed in the table.

yLinear (L), quadratic (Q) or cubic (C) effects significant at $P=0.05\left({ }^{*}\right), 0.01\left({ }^{* *}\right)$, or $0.001\left(^{* * *}\right)$ or nonsignificant (Ns).

Table 5. Effect of supplementary lighting $\left(100 \mu \mathrm{mol} \cdot \mathrm{s}^{-1} \cdot \mathrm{m}^{-2} ; \mathrm{PAR}\right)$ and four $\mathrm{N}$ levels on broccoli transplant growth (averages of three seeding

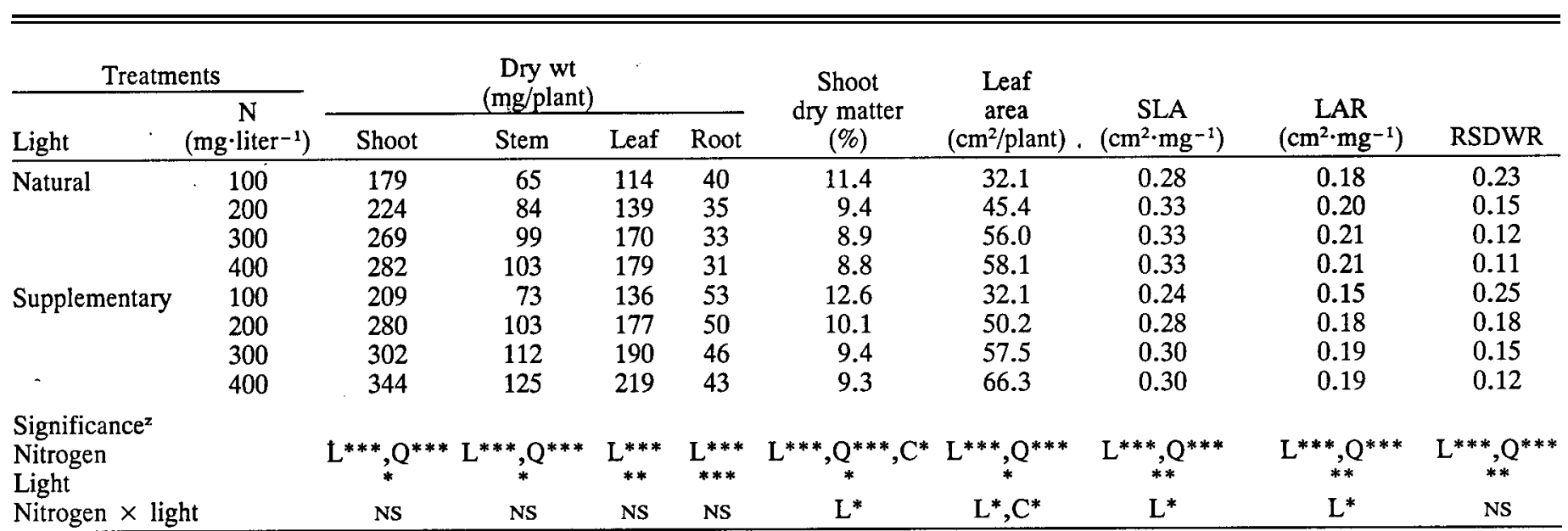

${ }^{2}$ Linear (L), quadratic (Q), or cubic (C) effects significant at $P=0.05\left({ }^{*}\right), 0.01\left({ }^{* *}\right)$, or $0.001\left({ }^{* * *}\right)$ or nonsignificant (NS).

Table 6. Effect of supplementay lighting $\left(100 \mu \mathrm{mol} \cdot \mathrm{s}^{-1} \cdot \mathrm{m}^{-2}\right.$; PAR)and four $\mathrm{N}$ levels on tomato transplant growth (averages of three seeding dates).

\begin{tabular}{|c|c|c|c|c|c|c|c|c|c|c|}
\hline \multicolumn{2}{|c|}{ Treatments } & \multicolumn{4}{|c|}{$\begin{array}{c}\text { Dry wt } \\
\text { (mg/plant) }\end{array}$} & \multirow{2}{*}{$\begin{array}{c}\text { Shoot } \\
\text { dry matter } \\
(\%)\end{array}$} & \multirow{2}{*}{$\begin{array}{c}\text { Leaf } \\
\text { area } \\
\left(\mathrm{cm}^{2} / \text { plant }\right)\end{array}$} & \multirow{2}{*}{$\begin{array}{c}\text { SLA } \\
\left(\mathrm{cm}^{2} \cdot \mathrm{mg}^{-1}\right) \\
\end{array}$} & \multirow{2}{*}{$\begin{array}{c}\mathrm{LAR} \\
\left(\mathrm{cm}^{2} \cdot \mathrm{mg}^{-1}\right) \\
\end{array}$} & \multirow[b]{2}{*}{ RSDWF } \\
\hline Light & $\left(\mathrm{mg} \cdot\right.$ liter $\left.^{-1}\right)$ & Shoot & Stem & Leaf & Root & & & & & \\
\hline \multirow[t]{4}{*}{ Natural } & 100 & 233 & 100 & 133 & 35 & 8.2 & 45.8 & 0.34 & 0.20 & 0.15 \\
\hline & 200 & 273 & 130 & 144 & 39 & 6.6 & 65.5 & 0.45 & 0.24 & 0.14 \\
\hline & 300 & 303 & 141 & 162 & 36 & 6.3 & 77.6 & 0.48 & 0.26 & 0.12 \\
\hline & 400 & 336 & 149 & 187 & 41 & 6.5 & 84.3 & 0.45 & 0.25 & 0.12 \\
\hline \multirow[t]{4}{*}{ Supplementary } & 100 & 294 & 124 & 170 & 40 & 9.8 & 45.0 & 0.27 & 0.16 & 0.14 \\
\hline & 200 & 363 & 162 & 201 & 48 & 7.7 & 74.1 & 0.37 & 0.20 & 0.13 \\
\hline & 300 & 373 & 171 & 202 & 48 & 7.1 & 83.8 & 0.42 & 0.23 & 0.13 \\
\hline & 400 & 393 & 177 & 216 & 46 & 7.1 & 90.8 & 0.42 & 0.23 & 0.12 \\
\hline \multicolumn{11}{|l|}{ Significance $^{z}$} \\
\hline \multicolumn{2}{|l|}{ Nitrogen } & $\mathrm{L}^{* * *}$ & $\mathrm{~L}^{* * *}, \mathrm{Q}^{* *}$ & $\mathrm{~L}^{* * *}$ & $\mathrm{~L}^{*}$ & $\mathrm{~L}^{* * *}, \mathrm{Q}^{* * *}$ & $\mathrm{~L}^{* * *}, \mathrm{Q}^{* * *}$ & $\mathrm{~L}^{* * *}, \mathrm{Q}^{* * *}$ & $\mathrm{~L}^{* * *}, \mathrm{Q}^{* * *}$ & $\mathrm{~L}^{* * *}$ \\
\hline \multirow{2}{*}{\multicolumn{2}{|c|}{$\begin{array}{l}\text { Light } \\
\text { Nitrocen } \times \text { light }\end{array}$}} & $* *$ & $*$ & $* *$ & $* *$ & $*$ & NS & ${ }^{*}$ & $*$ & NS \\
\hline & & NS & NS & NS & NS & $\mathrm{L}^{* *}$ & NS & $\mathrm{L}^{*}$ & NS & NS \\
\hline
\end{tabular}

${ }^{2}$ Linear (L) or quadratic (Q) effects significant at $P=0.05\left(^{*}\right), 0.01\left(^{* *}\right)$, or $0.001\left(^{* * *}\right.$ ) or nonsignificant (NS).

J. Amer. Soc. Hort. Sci. 116(4):594-598. 1991. 
affected (Table 3). For broccoli, the effects of $\mathrm{N}$ and supplementary lighting on the SLA were greater with early seedings (data not shown). For tomato, the increase in SLA with $\mathrm{N}$ fertilization was more pronounced under supplementary lighting.

Supplementary lighting reduced LAR in celery, broccoli, and tomato (Tables 3, 5, and 6). For broccoli, the effect of supplementary lighting on LAR was less in the late seedings, contrary to the observations for tomato (data not shown). Boivin et al. (1986) observed a lowering of LAR in greenhouse tomato transplants placed under increasing PPFD.

LAR of broccoli and tomato increased curvilinearly with $\mathrm{N}$ rate. Tremblay and Senécal (1988) reported increased LAR for broccoli and green pepper when plants were grown with 350 instead of $150 \mathrm{mg}$ N/liter. With broccoli, the response of LAR to $\mathrm{N}$ rate was greater without supplementary lighting (Table 5). The LAR and SLA of broccoli and tomato changed in a very similar way according to the lighting and fertilization treatments, thus indicating a similar response of leaves and stems. The effect of supplementary lighting and $\mathrm{N}$ on the LAR of tomato plants increased the later they were sown (data not shown).

Root dry weight and RSDWR Root dry weight of all species increased with supplementary lighting (Tables 3, 4, 5, and 6) by $97 \%, 42 \%, 38 \%$, and $21 \%$ for celery, lettuce, broccoli, and tomato, respectively. According to Weston and Zandstra (1986), transplants with a well-developed root system recover better in the field.

Increasing $\mathrm{N}$ fertilization decreased celery, lettuce, and broccoli root dry weight (Tables 3, 4, and 5). Tomato plants, however, showed a linear increase (Table 6), as noted by Weston and Zandstra (1989). Tomato root dry weight was $16 \%$ higher with 400 than with $100 \mathrm{mg}$ N/liter. Tremblay and Senécal (1988) reported a decrease in root weights of celery, lettuce, and broccoli caused by high rates of $\mathrm{N}$ fertilization.

The RSDWR of celery and broccoli was increased by supplementary lighting (Tables 3 and 5). However, lighting did not affect this relation for lettuce and tomato (Tables 4 and 6). RSDWR decreased curvilinearly in relation to $\mathrm{N}$ rate in celery, lettuce, and broccoli but linearly for tomato (Tables 3-6). Decreases in RSDWR caused by high $\mathrm{N}$ rates have been reported for several species (Dufault, 1985; Tremblay and Senécal, 1988; Tremblay et al., 1987; Weston and Zandstra, 1989). For celery and lettuce, this decrease was more evident under supplementary lighting.

In summary, the use of supplementary lighting (HPS) of 100 $\mu \mathrm{mol} \cdot \mathrm{s}^{-1} \cdot \mathrm{m}^{-2}$ (PAR) on seedlings during transplant production promoted balanced growth. Supplementary lighting also improved shoot and root dry weights of all species and it can be used in combination with high $\mathrm{N}$ fertilization for most of the species tested to obtain vigorous transplants, with acceptable levels of dry matter percentage. Supplementary lighting can be considered a promising technique to hasten production of good quality transplants in northern latitudes, particularly for early seeding dates. Nitrogen at $100 \mathrm{mg} \cdot \mathrm{liter}^{-1}$ limited growth of all the species. Rates of 300 to $400 \mathrm{mg}$ N/liter optimized growth of the transplants under natural light, while $400 \mathrm{mg}$ N/liter was generally optimal under supplementary lighting or when sowing was late. Since such high $\mathrm{N}$ levels may be detrimental to transplant survival under field conditions, it is therefore necessary to verify the consequences of this treatment in the field.

\section{Literature Cited}

Björkman, O. 1981. Response to different quantum flux densities, p. 57-107. In: O.L. Lange, P.S. Nobel, C.B. Osmond, and H. Zeigler (eds.). Responses to the physical environment. Physiol. Plant Ecol. 1. Encycl. of Plant Physiol. 12A. Springer-Verlag, Berlin.

Boivin, C., M.-J. Trudel, and A. Gosselin. 1986. Influence du niveau d'irradiance d'appoint (HPS) en pépinière sur la croissance d'une culture de tomate de serre. Can. J. Plant. Sci. 66:961-970.

Dufault, R.J. 1985. Relationship among nitrogen, phosphorus, and potassium fertility regimes on celery transplant growth. HortScience 20:1104-1106.

Dufault, R.J. 1986. Influence of nutritional conditioning on muskmelon transplant quality and early yield. J. Amer. Soc. Hort. Sci. 111:698-703.

Kratky, B.A. and H.Y. Mishima. 1981. Lettuce seeding and yield response to preplant and foliar fertilization during transplant production. J. Amer. Soc. Hort. Sci. 106:3-7.

Liptay, A., C.A. Jaworski, and S.C. Phatak. 1981. Effect of tomato transplant stem diameter and ethephon treatment on tomato yield, fruit size and number. Can. J. Plant Sci. 61:413415.

Masson, J., N. Tremblay, and A. Gosselin. 1990. Effets de la fertilisation azotée sur la croissance de transplants de tomate et de laitue cultivés en plateaux multicellulaires avec ou sans éclairage d'appoint. Can. J. Plant Sci. 70:1199-1205.

Salisbury, F.B. and C.W. Ross. 1985. Plant physiology. 3rd ed. Wadsworth Publishing, Belmont, Calif.

Tesi, R. and R. Tallarico. 1984. L'indurimento delle piantine di pomodoro in vivaio e loro resistenza al freddo. Colture Prolette 11:4954.

Thimijan, R.W. and R.D. Heins. 1983. Photometric, radiometric and quantum light units of measure: A review of procedures for interconversion. HortScience 18:818-822.

Tosi, D. and R. Tesi. 1987. Influenza dells concimazione del substrato sulla crescita di piantine di pomodoro in vivaio. Notiziario di Ortoflorofruitticoltura 2:67-73.

Tremblay, N. and A. Gosselin. 1989. Growth, nutrient status, and yield of celery seedlings in response to urea fertilization. HortScience 24:288-291.

Tremblay, N. and M. Senécal. 1988. Nitrogen and potassium in nutrient solution influence seedling growth of four vegetable species. HortScience 23:1018-1020.

Tremblay, N. and M. Senécal. 1990. Effets du mode d'irrigation et du contenu en urée de la solution fertilisante sur les caractéristiques de jeunes plants de brocoli, céleri et laitue. Agronomic 10:15-21.

Tremblay, N., S. Yelle, and A. Gosselin. 1987. Effects of $\mathrm{CO}_{2}$ enrichment, nitrogen and phosphorus fertilization on growth and yield of celery transplants. HortScience 22:875-876.

Weston, L.A. and B.H. Zandstra. 1986. Effect of root container size and location of production on growth and yield of tomato transplants. J. Amer. Soc. Hort. Sci. 111:498-501.

Weston, L.A. and B.H. Zandstra. 1989. Transplant age and $\mathrm{N}$ and $\mathrm{P}$ nutrition effects on growth and yield of tomatoes. HortScience 24:8890 